\title{
Methylprednisolone Prevention of Increased Lung Vascular Permeability following Endotoxemia in Sheep
}

\author{
Kenneth L. Brigham, Ronald E. Bowers, and Charles R. MCKeen, \\ Pulmonary Circulation Center, Vanderbilt University School of Medicine, \\ Nashville, Tennessee 37232
}

A B S T R A C T To see whether methylprednisolone would affect the pulmonary vascular response to endotoxemia, we studied responses to endotoxemia in the presence and absence of methylprednisolone in the same chronically instrumented, unanesthetized sheep. Infusion of Escherichia coli endotoxin (0.70-1.33 $\mu \mathrm{g} /$ $\mathrm{kg}$ ) caused an initial period of marked pulmonary hypertension followed several hours later by a long period of increased vascular permeability when pulmonary vascular pressures were near base line (baseline pulmonary artery pressure $(\mathrm{PPa})=21 \pm 1 \mathrm{~cm} \mathrm{H}_{2} \mathrm{O}$ $\mathrm{SE}$, left atrial pressure $(\mathrm{Pla})=1 \pm 3$; experimental $\mathrm{PPa}=20 \pm 3$, Pla $=3 \pm 4 ; P=N S)$, lung lymph flow (Q்lym) was high (base-line Q experimental Q $\operatorname{lym}=23.2 \pm 1.0 ; P<0.05)$ and lymph/ plasma protein concentration $(\mathrm{L} / \mathrm{P})$ was high (base-line $\mathrm{L} / \mathrm{P}=0.65 \pm 0.04 ;$ experimental $\mathrm{L} / \mathrm{P}=0.79 \pm 0.05 ; P$ $<0.05)$. When methylprednisolone $(1.0 \mathrm{~g}+0.5 \mathrm{~g} / \mathrm{h}$ i.v. $)$ was begun $30 \mathrm{~min}$ before the same dose of endotoxin was infused, the initial pulmonary hypertension was less and the late phase increase in lung vascular permeability was prevented (experimental $\mathrm{PPa}=24 \pm 1$, $\mathrm{Pla}=1 \pm 1, \dot{Q} \mathrm{lym}=10.0 \pm 0.4 ; \mathrm{L} / \mathrm{P}=0.56 \pm 0.03)$. $\dot{\mathrm{l}} \mathrm{lym}$ and $\mathrm{L} / \mathrm{P}$ were significantly $(P<0.05)$ lower than with endotoxin alone. Methylprednisolone began during the initial pulmonary hypertensive response to endotoxin also prevented the late phase increase in lung vascular permeability, but the drug had no effect once vascular permeability was increased. We conclude that large doses of methylprednisolone given before or soon after endotoxemia prevent the increase in lung vascular permeability that endotoxin causes, but do not reverse the abnormality once it occurs.

This work was done during Dr. Brigham's tenure as an Established Investigator of the American Heart Association. Received for publication 22 May 1980 and in revised form 10 December 1980.

\section{INTRODUCTION}

There are several theoretical reasons to expect corticosteroids to moderate the pulmonary vascular response to endotoxemia $(1,2)$, but a concensus about steroid effects has not emerged from available experimental and clinical data. In chronically instrumented unanesthetized sheep, we have reported a highly reproducible lung vascular response to infusing Escherichia coli endotoxin (3). There is an initial period of marked pulmonary hypertension and a late, steady-state phase of increased lung vascular permeability. Because the preparation is well-suited to the study of drug effects on the pulmonary vascular reaction to endotoxin and because increased lung vascular permeability appears to cause the pulmonary complications of gram negative sepsis in humans, we studied the effects of large doses of methylprednisolone on the endotoxin reaction in sheep.

We found that methylprednisolone given either prior to endotoxemia or during the initial period of pulmonary hypertension after endotoxemia, largely prevented the late phase increase in lung vascular permeability. However, methylprednisolone did not reverse the increase in permeability once it had occurred.

\section{METHODS}

\section{Experimental preparation}

We have published several descriptions of how we prepare sheep so that lung lymph can be collected and pressures measured (3-6). Through three thoracotomies we put catheters into the left atrium, pulmonary artery and the efferent duct from the caudal mediastinal lymph node. We ligated the tail of that node at the lower margin of the inferior pulmonary ligaments to eliminate systemic lymph (6) and put catheters through neck vessels into the superior vena cava and thoracic aorta. Sheep recovered from surgery and had a stable flow of blood free lymph by 3-5 d after surgery; then we made experiments. In sheep prepared this way, lymph flow in- 
creases when left atrial pressure is increased but not when right atrial pressure is increased by partial obstruction of the main pulmonary artery (6), supporting the assumption that the lymph comes mostly from the pulmonary circulation.

\section{Experimental protocols}

General. Throughout every experiment, sheep stood in a cage, unanesthetized, while we continuously recorded pulmonary arterial, left atrial and aortic pressures using strain gauges (Micron Instruments, Inc., Los Angeles, Calif.) and an electronic recorder (Hewlett-Packard Co., Palo Alto, Calif.). The zero reference for pressures was the level of the left atrium noted at surgery. We measured lung lymph flow by recording the amount accumulated in a graduated centrifuge tube each $15 \mathrm{~min}$. We collected aortic blood each hour and pooled lymph each half hour and measured their protein concentrations. None of the animals had received endotoxin prior to these studies. We measured $\mathrm{PO}_{2}, \mathrm{PCO}_{2}$, and $\mathrm{pH}$ in anaerobically collected arterial blood samples using an Instrumentation Laboratory blood gas analyzer (model 513, Instrumentation Laboratory, Inc., Lexington, Mass.).

Methylprednisolone control studies. Once in each of four sheep we measured responses to methylprednisolone infused intravenously with no other intervention. After a 1-2-h base-line period, we injected $1.0 \mathrm{~g}$ methylprednisolone through the superior vena cava catheter, then infused $0.5 \mathrm{~g} / \mathrm{h}$ methylprednisolone i.v. for $4 \mathrm{~h}$. We used methylprednisolone sodium succinate marketed for human use by Upjohn Co. (Kalamazoo, Mich.). The diluent supplied with each $1.0 \mathrm{~g}$ vial was used to dissolve the methylprednisolone immediately prior to infusion. The injected solution from each vial contained methylprednisolone sodium succinate equivalent to $1.0 \mathrm{~g}$ methylprednisolone, $12.8 \mathrm{mg}$ sodium biphosphate, 139.2 mg sodium phosphate, and $133.6 \mathrm{mg}$ benzyl alcohol in $16 \mathrm{ml}$. The same methylprednisolone and diluent preparations were used in all of the studies reported in this paper.

Methylprednisolone given before endotoxin. Five times in four sheep we did two experiments in random order, one with endotoxin alone and one with the same dose of endotoxin in the presence of methylprednisolone. In three of the five pairs of studies, methylprednisolone plus endotoxin was given first and in two pairs, endotoxin alone was given first. At least $48 \mathrm{~h}$ elapsed between the two studies in each pair of experiments.

In one of the pair of experiments, after a 1-2-h stable base-line period, we infused intravenously $0.70-1.33 \mu \mathrm{g} / \mathrm{kg}$ body wt, $E$. coli endotoxin over $30 \mathrm{~min}$. using a constant rate infusion pump (Harvard Apparatus Co., Inc., S. Natick, Mass.). In all experiments we used the same lot (number 3123-75) of endotoxin prepared according to the Westphal method by Difco Laboratories, Detroit, Mich. from E. coli 0127:B8. The endotoxin was dissolved in $20 \mathrm{ml}$ sterile, pyrogen-free $0.89 \% \mathrm{NaCl}$ solution immediately before beginning the infusion. We have shown in earlier studies that a given animal responds reproducibly to the same dose of this endotoxin preparation when at least $48 \mathrm{~h}$ elapses between endotoxin infusions; there is some variability among animals (3). In these studies, when endotoxin alone was the first experiment, we stopped the endotoxin infusion when pulmonary artery pressure exceeded $50 \mathrm{~cm} \mathrm{H}_{2} \mathrm{O}$ (an endotoxin dose of $0.70 \mu \mathrm{g} / \mathrm{kg}$ in one case and $1.33 \mu \mathrm{g} / \mathrm{kg}$ in the other); when methylprednisolone plus endotoxin was given in the first experiment, an endotoxin dose of $0.75 \mu \mathrm{g} / \mathrm{kg}$ was selected based on past experience (3). In each pair of studies, exactly the same dose of endotoxin was used in both experiments. After infusing endotoxin, we observed animals until at least $2 \mathrm{~h}$ of stable lymph flow and pressures were recorded.
The other experiment in each pair was identical except that $30 \mathrm{~min}$ before infusing endotoxin, we injected $1 \mathrm{~g}$ of methylprednisolone into the superior vena cava, then infused $0.5 \mathrm{~g} / \mathrm{h}$ methylprednisolone i.v. for $4 \mathrm{~h}$. In each pair of experiments, exactly the same dose and infusion rate of endotoxin was given.

Methylprednisolone given during the initial endotoxin response (phase I). In each of four sheep (different animals from those used above) we did two experiments in random order: $(a)$ endotoxin alone exactly as described above; $(b)$ the same dose of endotoxin with an intravenous infusion of methylprednisolone $(0.5 \mathrm{~g} / \mathrm{h}$ for $3 \mathrm{~h})$ begun when the pulmonary artery pressure response to endotoxin was maximal $(\sim 30 \mathrm{~min})$. In two animals, steroids were given in the first experiment and in the other two steroids were given in the second experiment. At least $48 \mathrm{~h}$ elapsed between studies. We continued all observations until at least $2 \mathrm{~h}$ of stable lymph flow and pressures were recorded.

Methylprednisolone given during the increased permeability response to endotoxin (phase II). Three times in three sheep we gave endotoxin alone exactly as above. When the second (high permeability) phase was well established (usually 3-4 h after endotoxin), we infused $1.0 \mathrm{~g}$ methylprednisolone ( $\sim 30 \mathrm{mg}$ methylprednisolone/kg body wt) over $30 \mathrm{~min}$ i.v. and continued to measure all parameters for $2-4 h$.

\section{Protein measurements}

We measured total protein concentrations in lymph and blood plasma by a modified biuret method (7) with an automated system (AutoAnalyzer, Technicon Instruments, Tarrytown, N. Y.); duplicate samples differed $<5 \%$.

We separated proteins in blood plasma and lymph samples from steady-state base-line and experimental periods by polyacrylamide gradient gel electrophoresis. The methods are described several times in the literature $(5,6)$. Using 4-30\% polyacrylamide gradient gels, we consistently identified eight protein fractions in plasma and lymph. To estimate the effective molecular radius of each fraction, we calibrated the gels with five proteins with known free diffusion coefficients. From a standard curve of migration distance plotted against Einstein-Stokes radius for the five known proteins we estimated the radius of the eight plasma and lymph fractions.

\section{Statistics}

We tested the significance of differences between steadystate base-line and experimental observations using a paired $t$ test (8). We also calculated means and standard errors for the steady-state data.

\section{RESULTS}

Methylprednisolone control studies. A typical experiment where methylprednisolone alone was infused is shown in Fig. 1 and data from four similar studies are summarized in Table I. Methylprednisolone had no significant effect on either pulmonary vascular pressures or lung lymph flow. There was a tendency for lymph protein concentration and lymph/ plasma concentration to decrease slightly, but the changes were not significant.

Methylprednisolone given before endotoxin. Fig. 2 

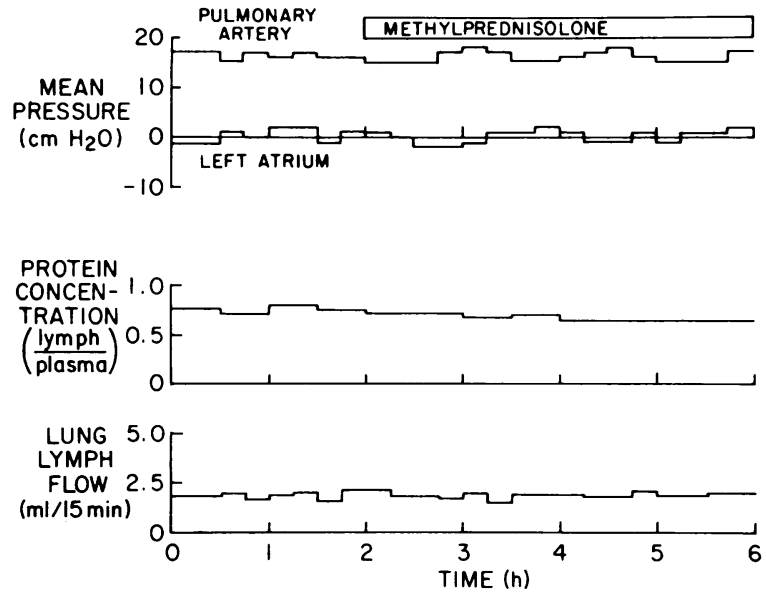

Figure 1 Effects of methylprednisolone (1.0-g bolus followed by $0.5 \mathrm{~g} / \mathrm{h}$ infusion) on pulmonary vascular pressures and lung lymph in a sheep.

illustrates a typical pair of experiments contrasting the effects of endotoxin in the presence and absence of methylprednisolone. The response to endotoxin was similar to that reported earlier (3) and the reaction was similar in animals given steroids plus endotoxin in a previous experiment to that in animals given endotoxin alone as their first experiment. There was an initial period of marked pulmonary hypertension, increasing lung lymph flow, and decreasing lymph/plasma protein concentration (phase I), followed in several hours by a steady-state period where pulmonary vascular pressures were stable, lung lymph flow was very high and lymph/plasma protein concentration was higher than base line (phase II). We define this late period of high flow of protein-rich lymph as the steady-state period of increased lung vascular permeability $(3,4,9)$; all variables returned to base line by $24-36 \mathrm{~h}$ after endotoxin infusion. When an infusion of methylprednisolone was begun before infusing endotoxin, animals did not develop clinical signs of sepsis (chills, restlessness) and the initial response to endotoxin was less; pulmonary artery pressure and lung lymph flow increased less than with endotoxin alone. The late phase increase in lung vascular permeability was prevented.

Table II summarizes base-line and experimental data from five pairs of experiments similar to those illustrated in Fig. 1. Methylprednisolone significantly reduced the early phase of the endotoxin reaction. In the late phase of the response, methylprednisolone had no significant effect on steady-state pulmonary vascular pressures, but dramatically reduced the lung lymph flow response. Methylprednisolone reduced the lymph flow response from greater than three times base line to 1.31 times base line and prevented increases in lymph protein concentration and lymph/plasma protein concentration.

Fig. 3 shows relationships between lymph/plasma protein concentration and lung lymph flow for late phase steady-state responses to endotoxin with and without methylprednisolone. Previously published data from studies where lung lymph flow was increased by elevating left atrial pressure are shown for comparison (10). Endotoxin, in striking contrast to left atrial pressure elevation, caused a very large increase in lung lymph flow with an increase in lymph/plasma protein concentration. This relationship means that lung vascular permeability to proteins was increased. Methylprednisolone eliminated the rise in lymph/ plasma protein concentration and almost eliminated the increase in lymph flow.

Fig. 4 shows steady-state lung lymph clearance of eight plasma protein fractions as a function of protein molecular radius during the base-line period and during the endotoxin response in the presence and absence of methylprednisolone. Lymph clearance of all proteins increased dramatically during the increased vascular permeability phase of the endotoxin response. In the presence of methylprednisolone, lymph clearance of all proteins was similiar to base line during the late-phase response to endotoxin.

The beneficial effects of methylprednisolone started

TABLE I

Effects of Methylprednisolone on Pulmonary Vascular Pressures and Lung Lymph (Mean $\pm S E M ; n=4)$

\begin{tabular}{|c|c|c|c|c|c|c|c|}
\hline \multirow[b]{2}{*}{ Condition } & \multirow[b]{2}{*}{$\begin{array}{l}\text { Body } \\
\text { weight }\end{array}$} & \multicolumn{2}{|c|}{$\begin{array}{l}\text { Mean pressure } \\
\left(\mathrm{cm} \mathrm{H}_{2} \mathrm{O}\right)\end{array}$} & \multirow[b]{2}{*}{$\begin{array}{c}\text { Lung } \\
\text { lymph flow }\end{array}$} & \multicolumn{3}{|c|}{ Total protein concentration $(\mathrm{g} / \mathrm{dl})$} \\
\hline & & $\begin{array}{c}\text { Pulmonary } \\
\text { artery }\end{array}$ & $\begin{array}{c}\text { Left } \\
\text { atrium }\end{array}$ & & Lymph & Plasma & $\frac{\text { Lymph }}{\text { Plasma }}$ \\
\hline & $k g$ & & & $m l / h$ & & & \\
\hline Base line* & $39.0 \pm 3.1$ & $19 \pm 2$ & $4 \pm 1$ & $6.6 \pm 1.1$ & $3.38 \pm 0.26$ & $5.40 \pm 0.16$ & $0.63 \pm 0.05$ \\
\hline Steroids* & $39.0 \pm 3.1$ & $19 \pm 2$ & $4 \pm 1$ & $7.5 \pm 1.2$ & $3.25 \pm 0.27$ & $5.62 \pm 0.15$ & $0.58 \pm 0.05$ \\
\hline
\end{tabular}

* Data are averaged over the entire base-line period and over the last $2 \mathrm{~h}$ of a 4 -h methylprednisolone infusion in each experiment. 


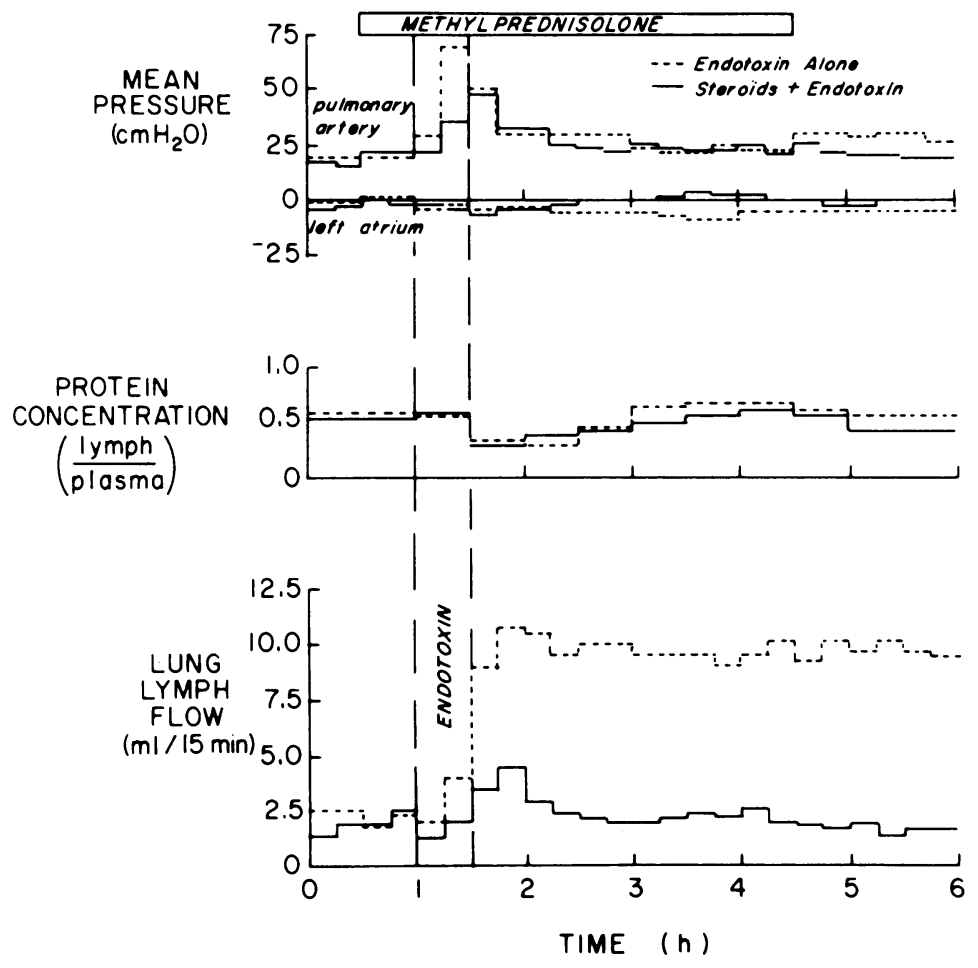

Figure 2 Comparison of the effects of endotoxin infusion in the presence and absence of methylprednisolone on different days in the same sheep. The endotoxin dose was identical in the two experiments. Methylprednisolone was begun $30 \mathrm{~min}$ before infusing endotoxin (see text for dose).

TABLE II

Summary of Hemodynamic and Lymph Data for Experiments with Endotoxin Given in the Presence and Absence of Methylprednisolone in the Same Sheep (Mean \pm SEM, $n=$ Five Studies in Four Sheep in Each Group)

\begin{tabular}{|c|c|c|c|c|c|c|c|}
\hline \multirow[b]{2}{*}{ Condition } & \multirow[b]{2}{*}{$\begin{array}{l}\text { Body } \\
\text { weight }\end{array}$} & \multicolumn{2}{|c|}{$\begin{array}{l}\text { Mean pressure } \\
\left(\mathrm{cm} \mathrm{H}_{2} \mathrm{O}\right)\end{array}$} & \multirow[b]{2}{*}{$\begin{array}{c}\text { Lung } \\
\text { lymph flow }\end{array}$} & \multicolumn{3}{|c|}{ Total protein concentration $(\mathrm{g} / \mathrm{dl})$} \\
\hline & & $\begin{array}{c}\text { Pulmonary } \\
\text { artery }\end{array}$ & $\begin{array}{c}\text { Left } \\
\text { atrium }\end{array}$ & & Lymph & Plasma & $\frac{\text { Lymph }}{\text { Plasma }}$ \\
\hline & $k g$ & & & $\mathrm{ml} / \mathrm{h}$ & & & \\
\hline Endotoxin alone & $41.0 \pm 2.5$ & & & & & & \\
\hline Base line* & & $21 \pm 1$ & $1 \pm 3$ & $7.2 \pm 0.2$ & $3.60 \pm 0.20$ & $5.60 \pm 0.10$ & $0.65 \pm 0.04$ \\
\hline Phase I & & $53 \pm 3$ & $-4 \pm 2$ & $45.4 \pm 2.8$ & $2.44 \pm 0.22$ & $5.76 \pm 0.15$ & $0.43 \pm 0.04$ \\
\hline Phase II $\S$ & & $20 \pm 3$ & $3 \pm 4$ & $23.2 \pm 1.0$ & $4.25 \pm 0.30$ & $5.40 \pm 1.00$ & $0.79 \pm 0.05$ \\
\hline Endotoxin + steroids & $41.0 \pm 2.5$ & & & & & & \\
\hline Base line* & & $21 \pm 1$ & $1 \pm 1$ & $7.6 \pm 0.4$ & $3.50 \pm 0.10$ & $5.22 \pm 0.18$ & $0.67 \pm 0.03$ \\
\hline Phase I & & $43 \pm 4^{\prime \prime}$ & $-4 \pm 1$ & $26.2 \pm 3.1^{11}$ & $2.68 \pm 0.14$ & $5.96 \pm 0.22$ & $0.45 \pm 0.03$ \\
\hline Phase II $\S$ & & $24 \pm 1$ & $1 \pm 1$ & $10.0 \pm 0.4^{\prime \prime}$ & $3.30 \pm 0.10^{\prime \prime}$ & $5.30 \pm 0.18$ & $0.56 \pm 0.03^{\prime \prime}$ \\
\hline
\end{tabular}

* Data averaged over entire base-line period in each experiment.

$\$$ Data are for the 15-min period when pulmonary artery pressure was highest, early in the endotoxin response (nonsteady state, see Fig. 2).

$\S$ Data are averaged over $1 \frac{1}{2}-2 \mathrm{~h}$ steady-state period occurring $3-5 \mathrm{~h}$ after infusing endotoxin in each experiment (see

Fig. 2). The same time periods after endotoxin were used in pairs of studies with and without steroids.

"Significantly different from endotoxin alone, $P<0.05$. 


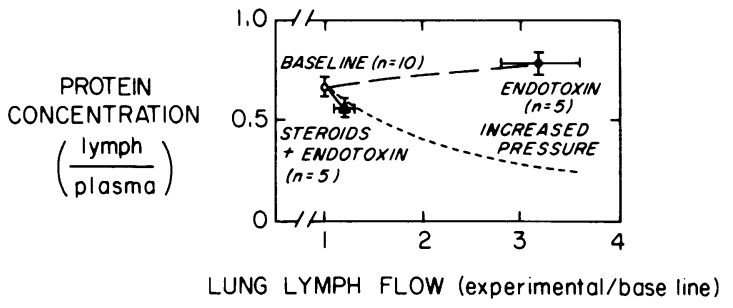

FIGURE 3 Relationships between lymph/plasma protein concentrations and lung lymph flows at base line and during steady-state responses to endotoxin with and without methylprednisolone given before endotoxin. The broken line is the relationship for other experiments where lymph flow wa's increased by elevating left atrial pressure (10).

before infusing endotoxin were also reflected in arterial blood gases. Average base-line values in the $10 \mathrm{ex}-$ periments were: $\mathrm{PO}_{2}=91 \pm 4 \mathrm{SE}$ torr, $\mathrm{PCO}_{2}=33 \pm 2 \mathrm{SE}$ torr, and $\mathrm{pH}=7.54 \pm 0.02 \mathrm{SE}$. During the late-phase response to endotoxin alone, $\mathrm{PO}_{2}$ decreased (to $83 \pm 7$, $P<0.05$ ) and $\mathrm{PCO}_{2}$ increased (to $38 \pm 3, P<0.05$ ); $\mathrm{pH}$ did not change significantly $(7.57 \pm 0.02, P=\mathrm{NS})$. During the same period after endotoxin in the presence of methylprednisolone, arterial blood gases were not significantly different from base line $\left(\mathrm{PO}_{2}=90 \pm 7\right.$; $\mathrm{PCO}_{2}=30 \pm 3 ; \mathrm{pH}=7.55 \pm 0.04 ; P=\mathrm{NS}$ for all three).

Methylprednisolone given during the initial endotoxin response (phase I). Fig. 5 shows a typical pair of experiments in a sheep, contrasting responses to endotoxin alone with responses to endotoxin when methylprednisolone was begun during the initial pul-

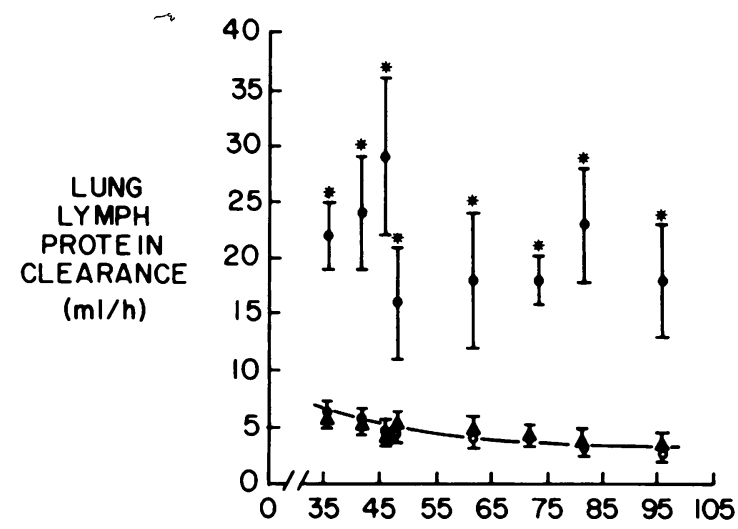

EFFECTIVE PROTEIN MOLECULAR RADIUS $(\AA)$

FIGURE 4 Steady-state lung lymph clearance (lymph flow $\times$ lymph/plasma concentration) for eight endogenous plasma protein fractions as a function of molecular radius. Data during base line and during the late phase response to endotoxin alone and endotoxin in the presence of methylprednisolone (begun before endotoxin) are shown. Bars are \pm SEM. endotoxin $(n=5) ; \boldsymbol{\Delta}$, steroids + endotoxin $(n=5)$; $\bigcirc$, base line $(n=10)$; $*$, significantly different from base line $(P<0.05)$.

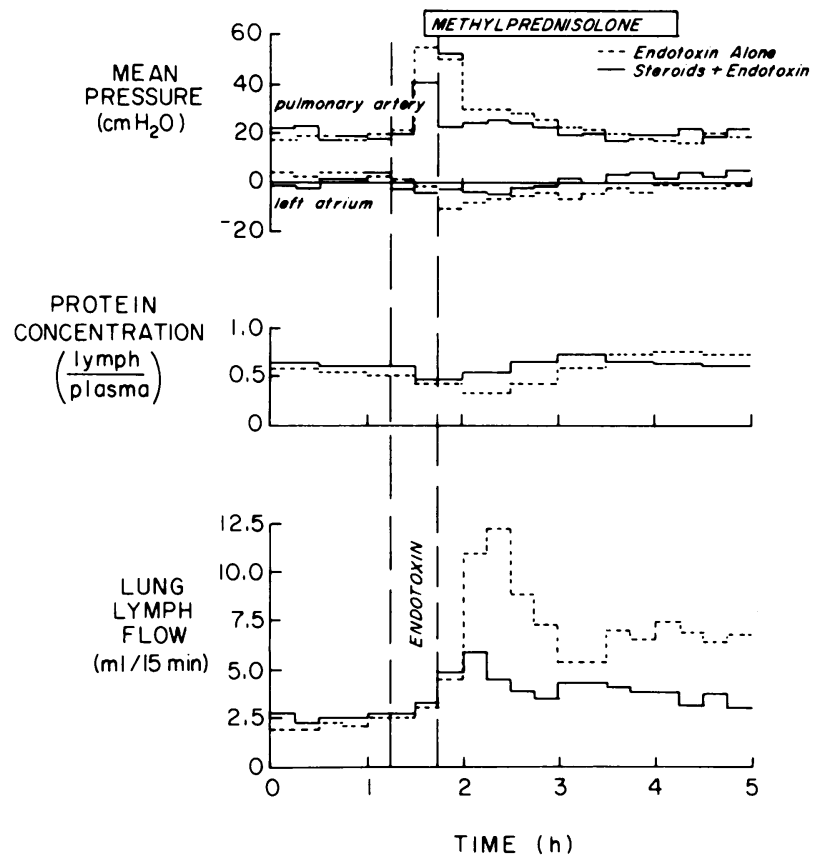

Figure 5 Responses of a sheep to the same dose of endotoxin on two different days. On one day endotoxin was given alone and on another day methylprednisolone (see text for dose) was begun during the initial period of pulmonary hypertension after endotoxin.

monary vascular response. In the presence of steroids given that way, lung lymph flow was substantially lower during the steady-state late phase of the endotoxin response.

Table III summarizes data from four pairs of experiments like the one illustrated in Fig. 5. On average, pulmonary artery pressures and lung lymph flows reached similar values in the first phase of the endotoxin response, but methylprednisolone begun during that period substantially reduced the late-phase lymph response. During the steady-state response to endotoxin alone, lung lymph flow was greater than three times base line and lymph/plasma protein concentration was higher than base line. During that same period in the presence of methylprednisolone, lymph flow was 1.3 times base line and lymph/plasma protein concentration was similar to base line.

Methylprednisolone given during the increased permeability response to endotoxin (phase II). Fig. 6 is typical of three experiments where methylprednisolone was infused during the steady state increased permeability response to endotoxemia. Although there was a tendency for pulmonary arterial pressure to decrease slightly after infusing the drug, there were no consistent effects on either lung lymph flow or lymph/plasma protein concentration. 
TABLE III

Summary of Hemodynamic and Lymph Data for Experiments with Endotoxin Given Alone and Methylprednisolone Given during the Phase I Endotoxin Response in the Same Sheep (Mean \pm SEM, $n=$ Four Studies in Four Sheep in Each Group)

\begin{tabular}{|c|c|c|c|c|c|c|c|}
\hline \multirow[b]{2}{*}{ Condition } & \multirow[b]{2}{*}{$\begin{array}{l}\text { Body } \\
\text { weight }\end{array}$} & \multicolumn{2}{|c|}{$\begin{array}{l}\text { Mean pressure } \\
\left(\mathrm{cm} \mathrm{H}_{2} \mathrm{O}\right)\end{array}$} & \multirow[b]{2}{*}{$\begin{array}{c}\text { Lung } \\
\text { lymph flow }\end{array}$} & \multicolumn{3}{|c|}{ Total protein concentration $(\mathrm{g} / \mathrm{dl})$} \\
\hline & & $\begin{array}{c}\text { Pulmonary } \\
\text { artery }\end{array}$ & $\begin{array}{l}\text { Left } \\
\text { atrium }\end{array}$ & & Lymph & Plasma & $\frac{\text { Lymph }}{\text { Plasma }}$ \\
\hline & $k g$ & & & $m l / h$ & & & \\
\hline Endotoxin alone & $33.5 \pm 1.6$ & & & & & & \\
\hline Base line* & & $22 \pm 3$ & $4 \pm 3$ & $9.5 \pm 3.1$ & $2.90 \pm 0.20$ & $5.60 \pm 1.00$ & $0.50 \pm 0.19$ \\
\hline Phase If & & $52 \pm 1$ & $-4 \pm 3$ & $39.8 \pm 2.0$ & $1.90 \pm 0.10$ & $5.90 \pm 0.20$ & $0.32 \pm 0.10$ \\
\hline Phase II $\S$ & & $22 \pm 3$ & $-2 \pm 2$ & $32.2 \pm 2.8$ & $3.30 \pm 0.30$ & $5.40 \pm 0.10$ & $0.61 \pm 0.06$ \\
\hline Endotoxin + steroids & $33.5 \pm 1.6$ & & & & & & \\
\hline Base line* & & $20 \pm 1$ & $0 \pm 1$ & $11.8 \pm 1.5$ & $3.40 \pm 0.30$ & $5.30 \pm 0.40$ & $0.64 \pm 0.02$ \\
\hline Phase It & & $50 \pm 2$ & $-4 \pm 1$ & $38.0 \pm 8.3$ & $2.40 \pm 0.30$ & $5.60 \pm 0.20$ & $0.43 \pm 0.04$ \\
\hline Phase II $\$$ & & $20 \pm 1$ & $3 \pm 1$ & $16.4 \pm 2.7^{\| \prime}$ & $3.30 \pm 0.27$ & $5.15 \pm 0.30$ & $0.63 \pm 0.03$ \\
\hline
\end{tabular}

* Data averaged over entire base-line period in each experiment.

$\$$ Data are for the 15-min period when pulmonary artery pressure was highest, early in the endotoxin response (nonsteady state, see Fig. 5).

$\$$ Data are averaged over $1 \frac{1}{1 / 2}-2 \mathrm{~h}$ steady-state period occurring 3-5 h after infusing endotoxin in each experiment (see Fig. 5). The same time periods after endotoxin were used in pairs of studies with and without steroids.

"Significantly different from endotoxin alone, $P<0.05$.

\section{DISCUSSION}

There is much evidence in the literature supporting the assumptions that, under steady state conditions, lung lymph flow and protein concentration reflect net

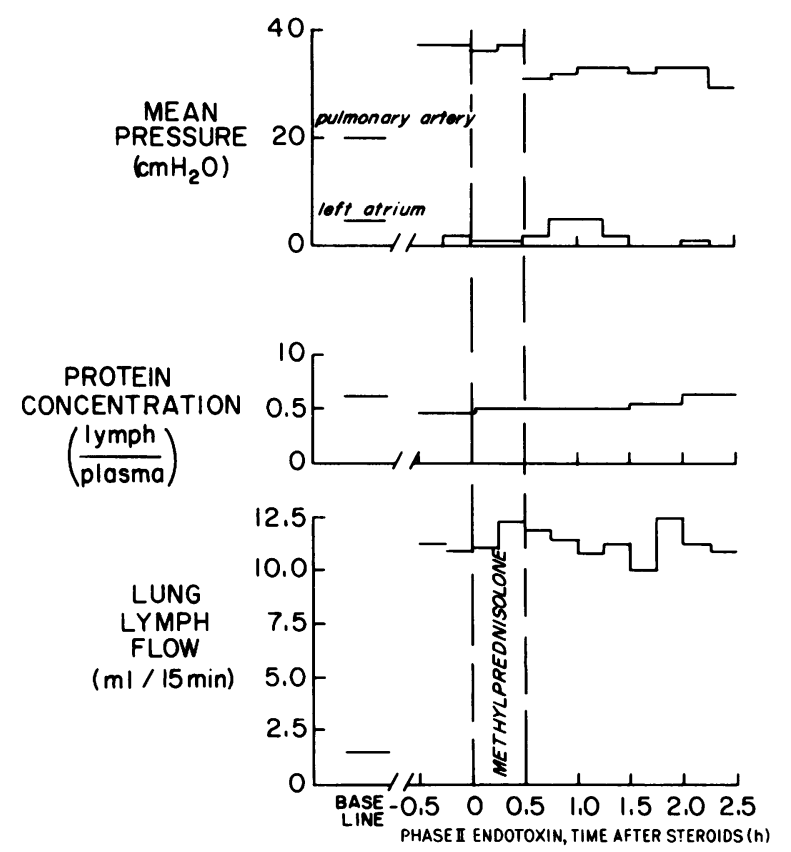

FIGURE 6 Effects of methylprednisolone $(1.0 \mathrm{~g}$ i.v.) given during the period of steady state increased vascular permeability after endotoxemia. transvascular fluid filtration rate and protein concentration in the filtrate $(11,12)$. If these assumptions are true, endotoxin infused into unanesthetized sheep causes an initial period of increased transvascular filtration in the lung resulting from pulmonary hypertension (high flow of protein poor lymph [3]), followed in several hours by a prolonged period of increased lung vascular permeability to fluid and protein (3). The evidence for increased permeability during that period is that pulmonary vascular pressures are stable at near base-line levels while lung lymph flow is high and lymph protein concentration is high. The relationship of lymph/plasma protein concentration to lung lymph flow (Fig. 3) is quite different than that relationship when lung lymph flow is increased because of elevated left atrial pressure. In the latter case lymph/plasma protein concentration falls as lymph flow increases. Thus, the steady-state endotoxin response cannot be due to increased microvascular pressure. That endotoxin increases lung vascular permeability to proteins is confirmed by the marked increase in lymph clearance of small and large proteins (Fig. 4).

In our experiments, high doses of methylprednisolone (in the range suggested for use in humans with septic shock [13]) given either before endotoxin or during the initial reaction to endotoxin largely prevented the late-phase increase in lung vascular permeability. The evidence for this is that, in the presence of methylprednisolone, lung lymph flow was near base line during the late phase of the endotoxin re- 
action and lymph/plasma protein concentration was not increased.

The steady-state phase of increased permeability after endotoxin allowed us to test the ability of methylprednisolone to reverse the abnormality. As illustrated in Fig. 6, methylprednisolone had no effect once permeability was increased.

At least under some circumstances, corticosteroids appear to inhibit endogenous production of arachidonate products prostaglandins, thromboxanes, and products of lipoxygenase apparently by preventing release of arachidonate from membrane phospholipids (1). Endotoxin infusion causes an increase in prostaglandins in blood (14) and lung lymph (15). Inhibition of arachidonate cyclooxygenase (which blocks prostaglandin and thromboxane synthesis) prevents the pulmonary hypertensive response to endotoxemia in calves (14) and sheep (16). Inhibiting prostaglandin synthesis does not prevent the late-phase increase in lung vascular permeability after endotoxemia in sheep, in fact, it appears to exaggerate the increase in permeability (16).This difference between the effects of steroids and nonsteroidal antiinflammatory drugs on the endotoxin response indicates that the steroid effect is not due only to inhibition of prostaglandin and thromboxane synthesis.

Corticosteroids could affect the endotoxin reaction indirectly by preventing fever, systemic hemodynamic changes, and other systemic responses to endotoxemia. Our data do not bear directly on the mechanism of the steroid effect, but the ability of high concentrations of corticosteroids to inhibit increased production of lipoxygenase products of arachidonate $(1,17,18)$ and to inhibit granulocyte aggregation $(2,19)$ merit attention. Our earlier studies suggest an important role for granulocytes in the pulmonary vascular response to endotoxemia (20), and a recent report indicates that SRS-A (a metabolite of arachidonate via lipoxygenase [21]) increases permeability in systemic microvessels (22).

Although extrapolating our data to the more complex clinical situation of gram negative sepsis is difficult, our findings that methylprednisolone given before or very early after endotoxemia prevents increased lung vascular permeability, but that, given late in the reaction, methylprednisolone has no effect, may be relevant to the controversy surrounding use of corticosteroids in humans with gram negative sepsis.

Schumer found that $30 \mathrm{mg} / \mathrm{kg}$ methylprednisolone given to patients "as soon as septic shock was clinically recognized" tripled survival (13). In contrast, Thompson and associates (23) found no increase in survival in septic patients given the same dose of methylprednisolone $9 \mathrm{~h}$ after shock was recognized (23). Detailed studies of the effects of steroids on survival in septic mice treated with antibiotics indicate that steroids have a beneficial effect only if given early in the course of sepsis (24). If our data are relevant to gram negative sepsis in humans, they suggest that prevention of pulmonary complications requires that the drug be given very early in the septic course.

Sibbald and associates (25), using clearance of intravenously injected radiolabeled albumin into airway secretions as a measure of "alveolo-capillary" permeability in humans with gram negative sepsis and respiratory failure, found that high doses of methylprednisolone given during periods of increased permeability would return permeability to normal (25). Our data appear different. Once lung vascular permeability was increased after endotoxemia, methylprednisolone had no effect. There are two obvious possible explanations for the disparity. Since alveolar epithelium is less permeable than capillary endothelium (26), epithelium is the primary barrier to movement of solutes from vascular space to airways. The data of Sibbald et al. (25) probably relate more to epithelial than endothelial permeability, whereas our data relate only to endothelial permeability. Corticosteroids could affect the two barriers differently. Perhaps more likely, humans may undergo repeated bouts of septicemia (and thus endotoxemia) so that giving steroids even after respiratory failure occurs may favorably affect responses to subsequent or concurrent endotoxemia.

Our data demonstrate that infusing $E$. coli endotoxin into unanesthetized sheep causes pulmonary hypertension initially, followed after several hours by a long period of increased lung vascular permeability. Large doses of methylprednisolone given before endotoxin largely prevent the response. Large doses of methylprednisolone begun during the early period of pulmonary hypertension largely prevent the later increase in permeability. Large doses of methylprednisolone given after permeability is increased do not reverse the abnormality. There are several possible explanations for the steroid effect. The clinical implications of our data may be that, given early in course of sepsis in humans, large doses of corticosteroids may help prevent the particularly devastating pulmonary complications of that disease.

\section{ACKNOWLEDGMENTS}

This work was supported by National Institutes of Health training grant 5 T32 HL 07123, National Heart, Lung and Blood Institute grant HL 19153 from the Specialized Center of Research in Pulmonary Vascular Diseases, the Parker B. Francis Foundation, the Hugh J. Morgan Fund for Cardiology, Martha Washington Straus-Harry H. Straus Foundation, and the John and Laura Cooke Fund for Lung Research.

\section{REFERENCES}

1. Hong, S., and L. Levine. 1976. Inhibition of arachidonic acid release from cells as the biochemical action of antiinflammatory steroids. Proc. Natl. Acad. Sci. U. S. A. 73: 1730-1734. 
2. Hammerschmidt, D., J. White, P. Craddock, and H. Jacob. 1979. Corticosteroids inhibit complement induced granulocyte aggregation. J. Clin. Invest. 63: 798-803.

3. Brigham, K., R. Bowers, and J. Haynes. 1979. Increased sheep lung vascular permeability caused by $\mathrm{E}$. coli endotoxin. Circ. Res 45: 292-297.

4. Brigham, K., R. Bowers, and P. Owen. 1976. Effects of antihistamines on the lung vascular response to histamine in unanesthetized sheep. Diphenhydramine prevention of pulmonary edema and increased permeability. J. Clin. Invest. 58: 391-398.

5. McKeen, C., K. Brigham, R. Bowers, and T. Harris. 1978. Effects of fat emulsion infusion in the lung circulation of unanesthetized sheep. Prevention with indomethacin. J. Clin. Invest. 61: 1291-1297.

6. Staub, N., R. Bland, K. Brigham, R. Demling, J. Erdmann, and W. Woolverton. 1975. Preparation of chronic lung lymph fistulas in sheep. J. Surg. Res. 19: 315-320.

7. Failing, J., M. Buckley, and D. Zak. 1960. Automatic determinations of serum proteins. Am. J. Pathol. 33: 83-88.

8. Snedecor, G., and W. Cochran. 1967. Statistical Methods. The Iowa State University Press, Ames, Iowa. 6th edition. 95-101.

9. Brigham, K., W. Woolverton, L. Blake, and N. Staub. 1974. Increased sheep lung vascular permeability caused by Pseudomonas bacteria. J. Clin. Invest. 54: 792-804.

10. Parker, R., R. Roselli, K. Brigham, and T. Harris. 1979. Lung microvascular protein sieving during acutely elevated left atrial pressure in sheep. Physiologist. 22: 98 (Abstr.).

11. Nicolaysen, G., A. Nicolaysen, and N. Staub. 1975. A quantitative radioautographic comparison of albumin concentration in different sized lymph vessels in normal mouse lungs. Microvasc. Res. 10: 138-152.

12. Vriem, C., P. Snashall, R. Demling, and N. Staub. 1976. Lung lymph and free interstitial fluid protein composition in sheep with edema. Am. J. Physiol. 230: 1650-1653.

13. Schumer, W. 1976. Steroids in the treatment of clinical septic shock. Ann. Surg. 184: 333-341.

14. Ancluson, F., T. Theofilos, W. Jubiz, and H. Kuida. 1975. Prostaglandin E and F levels during endotoxin induced pulmonary hypertension in calves. Ann. Surg. 184: 333-341.

15. Frolich, J., M. Ogletree, and K. Brigham. 1979. Pulmonary hypertension correlated to pulmonary thromboxane synthesis. Proceedings of the 4th Annual International Prostaglandin Conference. p. 38.

16. Ogletree, M., and K. Brigham. 1979. Indomethacin augments endotoxin induced increased lung vascular permeability in sheep. Am. Rev. Respir. Dis. 119: 383 (Abstr).

17. Burka, J., and R. Flower. 1979. Effects of modulators of arachidonic acid metabolism on the synthesis and release of slow reacting substance of anaphylaxis. $\mathrm{Br}$. J. Pharmacol. 65: 35-41.

18. Engineer, D., U. Niederhauser, P. Piper, and P. Sirois. 1978. Release of mediators of anaphylaxis: Inhibition of prostaglandin synthesis and the modification of release of slow reacting substance of anaphylaxis and histamine. Br. J. Pharmacol. 62: 61-66.

19. Craddock, P., J. Fehr, A. Dallmasso, H. Jacob, and K. Brigham. 1977. Hemodialysis leukopenia. Pulmonary vascular leukostasis resulting from complement activation by dialyzer cellophane membranes. J. Clin. Invest. 59: 879-888.

20. Heflin, C., and K. Brigham. 1979. Granulocyte depletion prevents increased lung vascular permeability after endotoxemia in sheep. Clin. Res. 27: 258A (Abstr.).

21. Samuelsson, B., and S. Hammarstrom. 1980. Nomenclature for leukotrienes. Prostaglandins. 19: 645-648.

22. Williams, T., and P. Piper. 1980 . The action of chemically pure SRS-A on the microcirculation in vivo. Prostaglandins. 19: 779-789.

23. Thompson, W., H. Gurley, B. Lutz, D. Jackson, L. Kuols, and I. Morris. 1976. Inefficacy of glucocorticoids in shock (double-blind study). Clin. Res. 24: 258A (Abstr.).

24. Greisman, S., J. DuBuy, and C. Woodward. 1979. Experimental gram-negative bacterial sepsis: prevention of mortality not preventable by antibiotics alone. Infect. Immun. 25: 538-557.

25. Anderson, R., W. Sibbald, R. Holliday, A. Driedger, and J. Duff. 1977. Increased pulmonary capillary permeability in human sepsis. Intensive Care Med. 3: 110 (Abstr.)

26. Staub, N. 1974. Pulmonary edema. Physiol. Rev. 54: $678-811$ 